\title{
Effect of Diversification Strategy, Leverage and IOS on Multi Segment Corporate Performance in Indonesia
}

\author{
MF Christiningrum \\ Institut Bisnis Nusantara; christiningrum@ibn.ac.id
}

Doi:10.5901/mjss.2015.v6n5s5p157

\begin{abstract}
This study examines the impact of diversification strategies, the level of use of debt (leverage) and the investment opportunity set (IOS) on the performance of diversified firms. Performance measurements using excess value (a proxy of market performance) and ROA (a proxy of accounting performance) is also discussed in this paper. This research includes measurement of diversification using the Herfindahl index and based on the number of corporate segments. The diversification strategies in this study are divided into 2 groups, namely, related and unrelated diversification of the firm's core business. The samples of this study are taken from all the multi-segment companies listed in the Indonesia Stock Exchange (IDX) for an 11year period from 2000 to 2010 and using panel data with a number of observations from 120 multi-segment companies $(1,320$ firm years). The test results indicate a negative effect of the implementation of diversification strategy on the firm's performance. The smaller the number of segments related to the core business, the better the market performance and as well as the accounting performance. The study also indicates that there is a quadratic relationship between diversification strategy and performance, i.e. increasing the number of segments, after reaching a certain optimum point, will discount the value of the company.
\end{abstract}

Keywords: related and unrelated diversification, leverage, investment opportunity set

\section{Introduction}

In the past few decades, business developments among various companies were made by building a multi-segment business strategy through diversification. The types of products produced and services provided within the framework of business development often differs significantly from its core competencies. This option is influenced by the desire to accelerate business development, improving ability of earnings, reducing risks, improving the ability to capture profit opportunities and competitiveness, as well as the allocation of resources and for the firms' competencies to be more effective and efficient. The debate on the impact of corporate diversification and its presence on the companies continue to emerge. Various studies suggest a premium effect with increased firm value (Markides, 1992; Villalonga, 2004; Bohl and $\mathrm{Pal}, 2006$ ), while other studies provide evidence of a discount effect that is a decrease in firm value (Lang and Stulz, 1994 ; Berger and Ofek, 1995; Rajan et al., 2000; Whited, 2001; Lamont and Polk, 2002; Xia, 2007).

Several studies related to the implementation of diversification strategy and its effect on firm performance (Palich et al., 2000; Matraves and Rodriguez, 2005; Galvan et al., 2007; Park and Jang, 2012) lead to the conclusion that the higher the level of diversification of the company through increasing the number of segments especially those unrelated, after having increased performance due to the implementation of this strategy, at a certain point will decrease in value creation. This is due to the increased internal transaction costs and reduced control in the highly-diverse business operations. These findings indicate that the selection of diversification strategy can have a positive effect on firm performance only at a certain point in time. If diversification continues to be developed by extending the segment, at some point the benefits will be reduced and tend to create discount effect on the performance of the company, so the relationship becomes quadratic (curvilinear).

Several studies related to the implementation of diversification strategy in Indonesia and its impact on firm performance are conducted, like the one made by Harto (2005), in the manufacturing industry, trade and property; Setionoputri et al., (2009), the effect before and after the adoption of SFAS No. 5 - Revised 2000 on firm value, Tifani (2010). From these studies, there has been no research specifically addressing whether diversifications are related to the core business (related diversification) or not related to the core (unrelated diversification) business which is an interesting study that needs to be conducted in more depth.

In Indonesia, many groups of companies built business segments that are initially not related to their respective core businesses. These companies believe that the acceleration of growth is done by relying on the opportunity, and not 
based on its core competencies. Although Prahalad and Hamel (1990) prove that the company that has a lot of diversification generally performs lower than the one that is focused on its core competencies, however, this strategy option remains attractive for companies. At the corporate level, control over business units is under the responsibility of the manager and not within the owners' control. This allows managers to pursue ambitions to expand business empires through the addition of business segments as quickly as possible, and sometimes, did not even consider the risks therein. Based on the above research, in order to explore the behavior of the companies that run the conglomerate strategy in Indonesia, there is a need to prove that there is no linear relationship between the related diversification strategy and unrelated effects on performance. In addition to examining the impact of the existence of a diversification strategy, there is also a need to examine the effect of leverage and the investment opportunity set (IOS) on performance. Comprehensive research on the behavior of diversification corporate (conglomeration) in Indonesia still has many limitations and should be investigated further. Based on the above explanation, it is interesting to do further research on using the diversification strategy.

This research is expected to contribute to the development of science related to the implementation of corporate diversification strategy on companies in Indonesia to: i) the creation of corporate value that can be measured through the performance of excess value (market performance) and ROA (accounting performance), which aims to prove whether the existence of conglomerate groups in Indonesia has premium effect on the performance or even the existence of such strategies provide discounts effect.

\section{Literature Review}

\subsection{Diversification}

Diversification is one of the strategies that companies use to compete in the business realm. Diversified companies are companies that have many business segments (multi-segment) or conglomerate, in which the segment can be classified into the related segment (segment that is still associated with its core business) and unrelated segments (variation of various segments and some are very different from its core business). According to Montgomery (1994) in Harto (2005) there are three perspectives motives to diversify. First, the market power view where diversification strategy can increase market share in the industry by reducing market competition because of its dominance, so that diversification will have a positive impact on company performance. Secondly, the resources-based view that diversification is done by utilizing the capacity of its resources. Third, the agency view which sees diversification stratefy as a tool to improve manager performance through increased sales.

Some researchers in diversification strategy, are able to prove the existence of a quadratic form of (curvilinear) between diversification and firm value (Galvan et al., 2007; Matraves and Rodriguez, 2005; Stern and Henderson, 2004; Palich et al., 2000), between the diversification and risk (Kahloul and Hallara, 2010), between the performance and the investment opportunity set in the group diversified firms (Morgado and Pindado, 2003) as well as between diversification and capital structure (Singh et al., 2003). These unlinear forms indicate that the selection of diversification strategy by adding segments initially resulted in the creation of value for the company, but continuing to increase the number of diversification will at some point lead to a decline in value creation.

\subsection{Resource Based Theory and Diversification}

According to Das and Teng (2000), resource-based view looks at the organization as a set of activities using the set of resources that it has. Wernerfelt (1984) in Das and Teng (2000) defines resources as assets, both tangible and intangible, is semi-permanently attached to the existence of the organization. There are two different views on the strategy of the organization. The traditional view relies on the analysis of the competitive environment, while the resourcebased view focuses on the resources with competitive advantages that are not easily imitated by others, so that the uniqueness enables the organization to grow into a strong organization.

\subsection{Market Power Theory and Diversification}

Market power theory states that the company can build excellence through market forces. From this theory point of view, winning the competition in the industry is a positive effect of multi-segment strategy. Although there are differences that related diversification can done for efficiency of economies scale, such as sharing of activities between business units, core competencies transfer, increasing market power and vertical integration. On the other hand, unrelated diversification 
aims to improve the efficiency of internal capital allocation and corporate restructuring of the business through the merger process. Despite the various advantages of diversification chosen to base this strategy, some studies suggest that the strategy of diversification leads to lower level of profitability (Rumelt, 1984; Davis et al., 1992, Singh et al., 2003). In fact, diversification strategy makes companies, which do not have core competencies and pursue only market demand which then led to the high of investment demands, difficult to fund the divisions within the group.

\subsection{Agency Theory and Diversification}

According to Jensen and Meckling (1976) the company is the nexus of contract between owners (principals) and managers (agents). In the contract, the owner delegates the authority to manage the company to the manager and the manager receives a reward for the services rendered. Final result that the owner expected is the maximization of the company value that ultimately enables the company to maintain its sustainable growth. According to some research, agency problems may lead to a decrease in the value of the company which operated using diversification strategy, due to the destructive effects produced by these strategies (Lang and Stulz, 1994; Berger and Ofek, 1995; Denis et al., 2002; Kahloul and Halara, 2010).

\subsection{Hypothesis Development}

\subsubsection{Strategy Effect of Diversification on Multi-Segment Firm Performance}

Diversification strategy that relies on multiple segments in developing the business, uses the market power theory and resource-based theory as basis for strengthening the company's corporate business. Opposing views on the benefits of this strategy are still ongoing despite numerous studies provide counter-arguments for each of these opposing views.

Some researchers indicate that profitability tends to be lower in the group of companies that decided to diversify (Rumelt, 1982; Davis et al., 1992), but the effect is different for each industry (Bettis and Hall, 1982), and not proven to produce enough valuable intangible assets (Lang and Stulz, 1994 and Servaes, 1996). While Rumelt (1982) proves that the decrease in performance occurs in firms with unrelated diversification by industry. The reason for this phenomenon is that these companies have the inherent advantage of being able to use the core skills that they have.

In Indonesia, evidence has not yet obtained related to the effect of diversification strategy on performance, whether the strategy gives the company discount or premium effect. Therefore, it is necessary for researchers to test the relationship between diversification strategies and the company performance, before then the related and unrelated diversification effects on performance is tested. Based on the description above, the hypotheses that is going to be tested in this research are:

H1a: Diversification strategies affect the performance of a multi-segment company

$1 \mathrm{~b}$ : Related diversification strategies have positive influence on the performance of multi-segment company

Research by Matraves and Rodriguez (2005) showed a curvilinear relationship between product diversification and profitability levels in Germany, and curvilinear relationship between geographic diversification and profitability levels in England. Diversification strategy and multinational strategies in Germany are complementary, while in the UK are interchangeable (substitution). Similarly, Thomas (2006) also found that U-shape curve occurs between international diversification strategy and performance of the company in Mexico. Further testing would like to see whether there is a quadratic relationship between the diversification and companies' performance in Indonesia. The hypothesis to be tested is:

H1c: Diversification strategy has a quadratic effect on the performance of a multi-segment company

\subsubsection{The Effect of Leverage on Performance of Multi-Segment Company}

Ross et al. (2008) stated that the use of debt will only benefit shareholders if and only if there is an increase in the value of the company. Therefore, managers may choose the composition of leverage which they believe will result in the highest performance. Research conducted Rhouland and Zhou (2005) found that companies which used diversified strategy substantially uses more debt and more profits to produce performance, and this result is consistent with research by Berger and Ofek (1995). In contrast, Morck, Shleifer and Vishny (1998) stated that the existence of the debt on a group of companies with diversified strategies cause decrease in the value of those companies. Although there are pros and contras on the effect of leverage on performance of multi-segment firms, it is believed that too much leverage will decrease firm performance (Morck, Shleifer, and Vishny, 1988; Mansi and Reeb, 2002). The hypothesis to be tested is: 


\section{H2: Leverage has positive effect on performance of a multi-segment company}

\subsubsection{The Effect of Investment Opportunity Set On Performance of Multi-Segment Company}

Kole (1991) stated that the value of IOS relies on discretionary of expenditure set by management in the future (future discretionary expenditure), which is currently the investment options that are expected to generate returns that amounted larger than the cost of equity. Diversified company basically has a chance to grow large, but they often have limitations in the availability of funds (Ferris et al., 2002), due to the need of the company to fund subsidiary companies which are still weak. Del Brio et al. (2003) stated furthermore that the effect of the investment on the market assessment, relying on free cash flow and investment opportunity set are owned by their respective companies.

Based on agency theory, Rajan et al. (2000) observed that there are frequent distortion in investment decisions, because managers often consider investment only based on the availability of opportunities, as well as free cash flow generating productive division without accounting the possibility of excessive investment (over-investment). Rajan et al. (2000) also see that if divisions have good resources and good opportunities, then the diversity focused and in line with its core business will generate positive performance for the company.

If the level of segment diversity is low as in the case of related diversification, the transfer of resources is on the right track and concentrated. This condition produces a better performance shown by excess value, than if the company is single segmented and can not reallocate resources in a similar manner to that of multi-segment company. In line with the increase of diversification, diversity can also increase the chance of investment thus resulting in a positive effect shown by the increase of the company's market performance. Krishnan and Kumar (2005) stated that the characteristics of firms with high IOS is that they are performing poorly in the accounting period (low contemporaneous earnings), but they have a high market performance shown by promising performance growth in the future (future earnings). Therefore, the proposed hypothesis as follows:

H3: Investment opportunity set (IOS) has positive effect on performance of multi-segment company

\section{Research Methodology}

\subsection{Population and Research Sample}

This study used samples of firms listed on the Indonesia Stock Exchange (IDX). Samples were taken from all companies in all industries except the financial industry and other industries that did not have the data of at least five companies specialized by industry sector, referring to Berger and Ofek (1995). Companies must have a complete set of financial statements, including segment reports and explanation. Observation period included 120 companies for the year 2000 to 2010 (11 years), resulting in 1,320 firm years.

\subsection{Model Tests on Effect of Diversification Strategy, Leverage and Investment Opportunity Set on Performance of Multi Segment Corporate}

This model is used to test $\mathrm{H} 1$ to $\mathrm{H} 3$ on the effect of diversification strategy and its quadratic relationship between the strategy and the performance of the company. The model also examines the effect of leverage and investment opportunity set on the performance of multi-segment company.

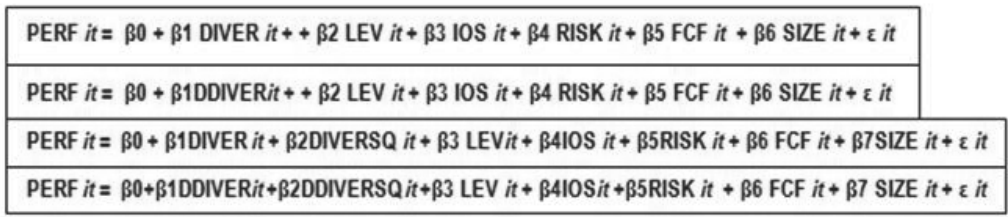

PERF it Performance of companies using 2 proxy: 1) excess value 2) ROA (return on total assets ratio) as a measure of accounting performance; DIVER it the level of diversification of the company, using two proxy measures: 1) Herfindahl Index (Berger and Ofek, 1995) and 2) number of segments.

DIVERSQ it the square of level of company diversification, to examine their curvilenear. DDIVER it Dummy 
strategic direction of company diversification (related atau unrelated diversification) using Shin measurement method (2006), which are Entropy Index (Jacquemin and Berry, 1979; Palepu, 1985) and Concentric Index (Montgomery and Wernerfelt, 1984). Given the value of 1 if related and 0 if unrelated. This dummy is then multiplied by the value of the variable DIVER. LEV it the ratio of total short-term debt and long-term debt to total long-term and the book value of equity. RISK it the magnitude of the systematic risk of the company (Beta of each stock). IOS it using Market-to-book assets ratio (Morck, Schleifer and Vishny, 1990). FCF it the magnitude of free cash flow, which can be distributed to creditors and shareholders, and no longer needed for working capital or investment in fixed assets (Ross et al., 2008). SIZE it firm size (logarithm of the book value of the company total assets)

\section{Results and Analysis}

\subsection{Results of Tests on Effect of Diversification Strategy, Leverage and IOS on The Performance of Multi-Segment Company}

The results of testing hypotheses $1 \mathrm{a}$ and $1 \mathrm{~b}$ found that the strategy of diversification by proxy the number of segments (QSEG) consistently affect the market performance and company accounting performance $(a=1 \%)$. The results show that the more of the number of company segments will decrease the market performance and the company accounting performance. Herfindahl Index $(\mathrm{HI})$ negatively effects $(\alpha=10 \%)$ on the market performance, indicating that the lower $\mathrm{HI}$ (the more sales company diversified into many segments), will increase the value of the company, but this result is not consistent with the test using ROA as measurement of accounting performance.The existence of contradiction regarding to the results of testing with proxy of $\mathrm{HI}$ and QSEG, indicating that if the company has a lower $\mathrm{HI}$, the sales generated by each segment are more even, so there is no segment that dominates the sales value of the company. While the higher value of $\mathrm{HI}$, the more likely there is a dominant segment of the business groups. For those who dominate the segment, it is probable that the greater to subsidize other segments that are not dominant, because the dominant segment generally performed better than the non-dominant segment.

Panel A: The effect of Diversification, Leverage and Investment Opportunity Set on Market Performance (Excess Value)

\begin{tabular}{|c|c|c|c|c|c|c|c|c|c|}
\hline \multicolumn{10}{|c|}{$\begin{array}{l}\text { Model 1a }: \text { PERF }_{i t}=\beta_{0}+\beta_{1} \text { DIVER }+\beta_{2} \text { LEV }+\beta_{3} \text { IOS }+\beta_{4} \text { RISK }+\beta_{5} \text { FCF }+\beta_{6} \text { SIZE }+\varepsilon \text { it } \\
\text { Model } 1 \mathrm{~b}: \text { PERF it }=\beta_{0}+\beta_{1} \text { DDIVER }+\beta_{2} \text { LEV }+\beta_{3} \text { IOS }+\beta_{4} \text { RISK }+\beta_{5} \text { FCF }+\beta_{6} \text { SIZE }+\varepsilon \text { it }\end{array}$} \\
\hline \multicolumn{10}{|c|}{ Variabel Dependen: EXVAL } \\
\hline \multirow{2}{*}{$\begin{array}{l}\text { Variabel } \\
\text { Independen }\end{array}$} & \multirow{2}{*}{ Prediksi } & \multicolumn{2}{|c|}{ (1) } & \multicolumn{2}{|c|}{ (2) } & \multicolumn{2}{|c|}{ (3) } & \multicolumn{2}{|c|}{ (4) } \\
\hline & & koefisien & p-value & koefisien & p-value & koefisien & p-value & koefisien & p-value \\
\hline C & $+/-$ & 10.81722 & $0.0000^{\star \star \star}$ & 10.61862 & $0.0000 * \star \star$ & 10.53313 & $0.0000^{\star \star \star}$ & 10.90445 & $0.0000^{\star * *}$ \\
\hline $\mathrm{HI}$ & - & -0.274245 & $0.0639 *$ & & & & & & \\
\hline $\mathrm{DHI}$ & + & & & -0.021993 & 0.8373 & & & & \\
\hline QSEG & - & & & & & -0.101935 & $0.0001^{* * *}$ & & \\
\hline DQSEG & + & & & & & & & -0.067190 & $0.0000^{\star \star \star}$ \\
\hline LEV & $+/-$ & -0.387937 & $0.0000^{\star \star *}$ & -0.410477 & $0.0000^{* * *}$ & -0.451063 & $0.0000^{* * *}$ & -0.442565 & $0.0000^{* * *}$ \\
\hline IOS & + & 0.519909 & $0.0000^{\star \star *}$ & 0.522915 & $0.0000 * \star \star$ & 0.518398 & $0.0000 * * *$ & 0.524382 & $0.0000^{* * *}$ \\
\hline RISK & - & -0.023233 & 0.1181 & -0.020609 & 0.1677 & -0.016436 & 0.2702 & -0.021571 & 0.1466 \\
\hline FCF & - & -0.000429 & $0.0000^{\star \star *}$ & -0.000432 & $0.0000^{\star * *}$ & -0.000395 & $0.0000^{* * *}$ & -0.000425 & $0.0000^{* * *}$ \\
\hline LNTA & $+/-$ & -0.437150 & $0.0000^{\star \star *}$ & -0.435713 & $0.0000^{\star * *}$ & -0.421005 & $0.0000^{\star \star \star}$ & -0.439934 & $0.0000^{* * \star}$ \\
\hline R-squared & & 0.864213 & & 0.863312 & & 0.863643 & & 0.862881 & \\
\hline Adj R-squared & & 0.849998 & & 0.849003 & & 0.849367 & & 0.848526 & \\
\hline
\end{tabular}

The above conclusion is supported by a test using a proxy number of segments (QSEG), which indicates that increasing the number of segments will degrade the performance of the company. This means that companies with an increasing number of segments, but sales dominance is only in certain segments, the better performance of the dominant segment will be absorbed to fund low-performing segment (poor performing). This finding is consistent with Davis et al. (1992) and Singh et al. (2003) who stated that strategy of diversification can lead to low level of profitability, particularly diversification from a few dominant segment.

The test also shows a significant negative effect $(\alpha=1 \%)$ for a related diversification (DQSEG) on the performance of the enterprise market, but has no effect on accounting performance. Consistent with the previous explanation, that the company only has a few segments and focus on its core competencies, can generally achieve better efficiency levels. Firms with related diversification strategy generally have a stronger resource based, which allows for the use of strategic assets together. In addition, the companies also have a resource that expertise is higher because the majority of 
businesses rely on core competencies. The condition is well read by the market as reflected in the increase in excess value. This is in line with the opinion of Prahalad and Hamel (1990) about the importance of core competence, as well as the opinion of Galvan et al. (2007) and Chang and Wang (2007) who states that the focus on the core business of the company will result in a better market performance. In addition to diversification strategies, test results shows an increase in leverage will decrease the excess value and ROA $(a=1 \%)$. The creation of an internal capital market among segments advanced by Rhouland and Zhou (2005) and Perez and Hemmen (2010) is not sufficiently reliable as a source of corporate funding. Financing on investment in segments especially unrelated, forcing the company to take external funding sources (Comment and Jarell, 1995). Ultimately increase the debt will increase the interest costs, and also increase the default risk of firm. This resulted in a decline in market performance (excess value) of company. This finding is consistent with the opinion of Perez and Hemmen (2010).

Multi-segment strategy offers vast investment opportunities because the development of the market and the products it produces. The test shows consistent results related IOS positive influence on the accounting performance and market performance of the company $(a=1 \%)$. This finding is in line with Rajan et al. (2000) who argues that diversification can increase investment opportunities and provide a positive influence on company performance improvement. Krishnan and Kumar (2005) gives another opinion, according to the company with a high IOS will have lower accounting performance in the current period (low contemporaneous earnings), in order to promise the investors a better future gains. The result shows a significant positive relationship of iOS influence on ROA. The result is contrary to the findings of Krishnan and Kumar (2005). The argument that can be delivered is a company with a high IOS generally requires greater funds to finance capital goods, and will try to find the sources of funding in the capital markets. Companies tend not to rely on sources of funding of the bank when the value of collateral (collateral) held is insufficient. Efforts to obtain funding from the capital markets should be supported by good accounting performance, supposedly the company will strive to present a positive performance through good ROA to prospective investors.

Panel B: The effect of Diversification, Leverage and Investment Opportunity Set On Accounting Performance (ROA)

\begin{tabular}{|c|c|c|c|c|c|c|c|c|c|}
\hline \multirow{2}{*}{\multicolumn{10}{|c|}{$\begin{array}{l}\text { Model 1a : PERF it }=\beta_{0}+\beta_{1} \text { DIVER }+\beta_{2} \text { LEVERAGE }+\beta_{3} \text { IOS }+\beta_{4} \text { RISK }+\beta_{5} \text { FCF }+\beta_{6} \text { SIZE }+\varepsilon \text { it } \\
\text { Model } 1 \mathrm{~b}: \text { PERF }=\beta_{0}+\beta_{1} \text { DDIVER }+\beta_{2} \text { LEVERAGE }+\beta_{3} \text { IOS }+\beta_{4} \text { RISK }+\beta_{5} \text { FCF }+\beta_{6} \text { SIZE }+\varepsilon \text { it } \\
\text { Dependent Variable: ROA }\end{array}$}} \\
\hline & & & & & & & & & \\
\hline \multirow{2}{*}{ Independent Variables } & \multirow{2}{*}{ Prediction } & \multicolumn{2}{|c|}{\begin{tabular}{|c|} 
(1) \\
\end{tabular}} & \multicolumn{2}{|c|}{\begin{tabular}{|l|} 
(2) \\
\end{tabular}} & \multicolumn{2}{|c|}{ (3) } & \multicolumn{2}{|c|}{ (4) } \\
\hline & & Coefficient & $p$-value & Coefficient & $p$-value & Coefficient & $p$-value & Coefficient & $p$-value \\
\hline $\mathrm{C}$ & $+/-$ & -0.174132 & $0.0037^{\star \star \star}$ & -0.174644 & $0.0041^{\star \star \star}$ & -0.142458 & $0.0199 \star \star$ & -0.179354 & $0.0032^{\star \star \star}$ \\
\hline $\mathrm{HI}$ & - & -0.008250 & 0.2552 & & & & & & \\
\hline DHI & + & & & 0.001835 & 0.7556 & & & & \\
\hline QSEG & & & & & & -0.004777 & $0.0019^{* \star \star}$ & & \\
\hline DQSEG & + & & & & & & & 0.000409 & 0.6312 \\
\hline LEVERAGE & $+1-$ & -0.055734 & $0.0000^{\star \star \star}$ & -0.057900 & $0.0000^{\star * \star}$ & -0.058065 & $0.0000^{* \star \star}$ & -0.057406 & $0.0000^{\star \star \star}$ \\
\hline IOS & + & 0.007403 & $0.0001^{\star \star \star}$ & 0.007855 & $0.0000^{\star * \star}$ & 0.007860 & $0.0000^{* \star *}$ & 0.007793 & $0.0000^{\star \star *}$ \\
\hline RISK & - & $-3.34 \mathrm{E}-05$ & 0.9730 & $-4.88 \mathrm{E}-05$ & 0.9603 & -0.000237 & 0.8090 & $-5.07 \mathrm{E}-05$ & 0.9585 \\
\hline FCF & - & $-2.26 \mathrm{E}-05$ & $0.0000^{\star \star \star}$ & $-2.14 \mathrm{E}-05$ & $0.0000^{\star \star \star}$ & $-1.98 \mathrm{E}-05$ & $0.0000^{\star \star \star}$ & $-2.18 \mathrm{E}-05$ & $0.0000^{\star \star \star}$ \\
\hline SIZE (LNTA) & $+1-$ & 0.008590 & $0.0001^{\star \star \star}$ & 0.008396 & $0.0002^{\star \star *}$ & 0.007795 & $0.0004^{\star \star \star}$ & 0.008561 & $0.0001^{\star \star \star}$ \\
\hline R-Squared & & 0.737074 & & 0.728821 & & 0.732357 & & 0.729852 & \\
\hline Adj R-Squared & & 0.709548 & & 0.700431 & & 0.704338 & & 0.701570 & \\
\hline
\end{tabular}

Another alternative funding can come from the bank if collateral is sufficient, then good accounting performance is required. The tightness of debt covenant requirements led to opportunistic motives, which are supposed to influence on the presentation of accounting profit companies with high IOS. Although according to Gull et al. (2003), companies with high IOS will attempt to convey credible and relevant information, so earning management should have more motivated efficiently. The control variable FCF negatively affects the market performance and accounting, which indicate that the management is less efficient in the use of their free cash flow. Generally, companies with multi-segment strategy have a high investment opportunities, so they require a lot of funds to finance investment. The higher FCF indicates the inability to use the firm's cash flow and will further degrade the company performance. This finding is consistent with Lang et al. (1996) and Gull \& Jaggi (1999), who state that the company performance is strongly influenced by its ability to manage its free cash flow efficiently. Firm size as a control variable giving inconsistent results on the performance of the market and accounting performance. The test result shows that the bigger companies will lower the excess value (EXVAL). This indicates that the market doubts the sustainable growth of companies with increasing number of segments. This reaction is consistent with the results of previous tests that the number of segments negatively affect EXVAL. Bauwhede (2003) 
argues that this condition is due to the tendency of large firms to increase the number of unrelated segments, which are no longer focused on its core business (Nelson, 2003; Anderson and de Palma, 1992).

Inconsistent result shows in an increase in ROA in line with the increasing of the company size. The companies tend to deliver earnings and better accounting performance, when the size of the company is bigger. Managers tend to try to show a good ROA in the course of building a business empire (empire building). This trend is closely related to the desire to obtain trust from creditors, investors and other stakeholders. The test results on the quality of earnings will try to find empirical evidence of management's opportunistic motives in presenting the accounting performance of multisegment firms.

\subsection{Testing Results in Quadratic Influence of Diversification Strategy, Leverage, and IOS on Performance of Multi- Segment Firms}

Curvilinear form of the model testing $1 \mathrm{c}$ and $1 \mathrm{~d}$ indicated by the positive coefficients of DIVER and negative DIVERSQ. Positive direction of coefficient DIVER (proxied by DQSEG) shows that the diversification strategy will have an impact on increasing the firm's market performance, but if adding the segment continued, with unequal strength of segments, will give the company the market slowdown. Effects originally produced premium turns into a discount for the effect of the company's performance, visible from DQSEGSQ a negative effect on $a=1 \%$. This is consistent with Hypothesis $1 \mathrm{c}$ stated shaped linear relationship between diversification on performance. Not all of the testing on the model $1 \mathrm{c}$ gives significant results. The test results shows that only a proxy for the number of related segments quadratic (DQSEGSQ) proves significantly the curvilinear forms $(\alpha=1 \%)$ on the market performance. This result indicates that the addition of the segment number increasing, although the segment is related, but after a certain optimal point, the addition of the segment is no longer effective in increasing the excess value.

The market does not appreciate the addition of many segments, because they suspect that not all segments will be productive. In testing using $\mathrm{HI}$ and $\mathrm{DHI}$, the quadratic model is not proven. If using a proxy $\mathrm{HI}$ (which shows the spread of sales in various segments), evenly or not the sales of the various segments do not significantly form the curvilinear, so that continues to be done, with dominant sales value only in a few of segments ( $\mathrm{HI}$ rising), then after reaching the maximum performance, the increase of QSEG and $\mathrm{HI}$ will affect the decrease of ROA.

Panel C: The effect of Diversification, Leverage and Investment Opportunity Set On Market Performance (Excess Value)

\begin{tabular}{|c|c|c|c|c|c|c|c|c|c|}
\hline \multicolumn{10}{|c|}{$\begin{array}{l}\text { Model 1c: } \text { PERF }_{\text {it }}=\beta_{0}+\beta_{1} \text { DIVER }+\beta_{2} \text { DIVERSQ }+\beta_{3} \text { LEV }+\beta_{4} \text { IOS }+\beta_{5} \text { RISK }+\beta_{6} \text { FCF }+\beta_{7} \text { SIZE }+\varepsilon \text { it } \\
\text { Model 1d: PERF } i t=\beta_{0}+\beta_{1} \text { DDIVER }+\beta_{2} \text { DIVERSQ }+\beta_{3} \text { LEV }+\beta_{4} \text { IOS }+\beta_{5} \text { RISK }+\beta_{6} \text { FCF }+\beta_{7} \text { SIZE }+\varepsilon \text { it } \\
\text { Variabel Dependen: EXVAL }\end{array}$} \\
\hline \multirow{2}{*}{ Independent Variables } & \multirow{2}{*}{ Prediction } & \multicolumn{2}{|c|}{\begin{tabular}{|c|}
$(1)$ \\
\end{tabular}} & \multicolumn{2}{|c|}{ (2) } & \multicolumn{2}{|c|}{\begin{tabular}{|c|}
$(3)$ \\
\end{tabular}} & \multicolumn{2}{|c|}{ (4) } \\
\hline & & Coefficient & p-value & Coefficient & p-value & Coefficient & $p$-value & Coefficient & $p$-value \\
\hline $\mathrm{C}$ & $+/-$ & 10.53741 & $0.0000^{\star * *}$ & 10.44946 & $0.0000^{* \star *}$ & 10.51703 & $0.0000^{* \star *}$ & 10.79761 & $0.0000^{\star \star *}$ \\
\hline $\mathrm{HI}$ & + & 0.111840 & 0.8813 & & & & & & \\
\hline HISQ & - & -0.306495 & 0.5861 & & & & & & \\
\hline $\mathrm{DHI}$ & + & & & 0.411089 & 0.2109 & & & & \\
\hline DHISQ & - & & & -0.428748 & 0.1570 & & & & \\
\hline QSEG & - & & & & & -0.102971 & 0.2329 & & \\
\hline Q'SEGSQ & + & & & & & 3.93E-06 & 0.9997 & & \\
\hline DQSEG & + & & & & & & & 0.057697 & 0.2514 \\
\hline DQSEGSQ & - & & & & & & & -0.017373 & $0.0092^{\star \star *}$ \\
\hline LEV & - & -0.390594 & $0.0000^{* * *}$ & -0.398344 & $0.0000 * * *$ & -0.451663 & $0.0000^{* * *}$ & -0.431232 & $0.0000^{* * *}$ \\
\hline IOS & + & 0.520265 & $0.0000^{\star * *}$ & 0.522366 & $0.0000^{* * *}$ & 0.517029 & $0.0000^{\star \star *}$ & 0.524097 & $0.0000^{\star * *}$ \\
\hline RISK & + & -0.023222 & 0.1196 & -0.020365 & 0.1740 & -0.016484 & 0.2696 & -0.016559 & 0.2675 \\
\hline FCF & - & -0.427636 & $0.0000^{* * *}$ & -0.428925 & $0.0000^{* * *}$ & -0.394599 & $0.0000^{* \star *}$ & -0.411650 & $0.0000^{* * *}$ \\
\hline SIZE (LNTA) & $+1-$ & -0.430834 & $0.0000^{* * *}$ & -0.432129 & $0.0000^{* * *}$ & -0.420232 & $0.0000^{\star \star *}$ & -0.441988 & $0.0000^{\star * *}$ \\
\hline R-squared & & 0.864555 & & 0.864069 & & 0.863577 & & 0.863820 & \\
\hline Adj R-squared & & 0.850250 & & 0.849713 & & 0.849168 & & 0.849437 & \\
\hline
\end{tabular}

This indicates that not all segments are developed in diversified firms able to generate positive performance, and often these segments rely and become a burden for the productive segments that performs well. These results are consistent with Hypothesis 1c. Through internal capital market mechanism within the firms, the need for funds is charged to productive segments causes the limitation of the segment to grow well, because these segments have the obligation to support and subsidize the weaker segments. This condition causes a decline in performance with increasing number of 
segments. The findings proved by Palich (2000), Thomas (2006), Galván (2007) and Kahloul and Hallara (2010). They state in particular point the increase in diversity will produce discount effects found in this study, although not all diversification proxies are able to prove the hypothesis.

Panel D: The Effect of Quadratic Diversification Strategy, Leverage, and Investment Opportunity Set on Accounting Performance (ROA)

\begin{tabular}{|c|c|c|c|c|c|c|c|c|c|}
\hline \multicolumn{10}{|c|}{$\begin{array}{l}\text { Model 1c: PERF it }=\beta_{0}+\beta_{1} \text { DIVER }+\beta_{2} \text { DIVERSQ }+\beta_{3} \text { LEV }+\beta_{4} \text { IOS }+\beta_{5} \text { RISK }+\beta_{6} \text { FCF }+\beta_{7} \text { SIZE }+\varepsilon_{\text {it }} \\
\text { Model 1d: PERF it }=\beta_{0}+\beta_{1} \text { DDIVER }+\beta_{2} \text { DIVERSQ }+\beta_{3} \text { LEV }+\beta_{4} \text { IOS }+\beta_{5} \text { RISK }+\beta_{6} \text { FCF }+\beta_{7} \text { SIZE }+\varepsilon_{\text {it }} \\
\text { Variabel Dependen: ROA }\end{array}$} \\
\hline \multirow{2}{*}{ Independent Variables } & \multirow{2}{*}{ Prediction } & \multicolumn{2}{|c|}{ (1) } & \multicolumn{2}{|c|}{ (2) } & \multicolumn{2}{|c|}{ (3) } & \multicolumn{2}{|c|}{$(4)$} \\
\hline & & coefficient & $p$-value & coefficient & $p$-value & coefficient & $p$-value & coefficient & $\mathrm{p}$-value \\
\hline C & $+1-$ & -0.192901 & $0.0027^{\star * \star}$ & -0.195812 & $0.0019^{* \star \star}$ & -0.150903 & $0.0132^{* *}$ & -0.176856 & $0.0045^{\star \star \star}$ \\
\hline$H$ & + & 0.027522 & 0.5086 & & & & & & \\
\hline HISQ & - & -0.026964 & 0.3821 & & & & & & \\
\hline $\mathrm{HI}$ & + & & & 0.039144 & $0.0506^{*}$ & & & & \\
\hline & - & & & -0.035099 & $0.0450^{\star *}$ & & & & \\
\hline QSEG & + & & & & & 0.003986 & 0.4198 & & \\
\hline & - & & & & & -0.001271 & $0.0657^{*}$ & & \\
\hline DQSE & + & & & & & & & 0.004146 & 0.2018 \\
\hline DQSEGSQ & & & & & & & & -0.000554 & 0.1814 \\
\hline LEV & $+1-$ & -0.055335 & $0.0000^{\star \star *}$ & -0.055768 & $0.0000^{* \star *}$ & -0.056409 & $0.0000^{\star \star \star}$ & -0.056460 & $0.0000^{\star \star \star}$ \\
\hline 105 & + & 0.007447 & $0.0001^{* \star *}$ & 0.007516 & $0.0001^{* * *}$ & 0.007664 & $0.0000^{\star \star *}$ & 0.007544 & $0.0001^{\star \star \star}$ \\
\hline RISK & - & $-8.38 \mathrm{E}-05$ & 0.9323 & -0.000194 & 0.8452 & -0.000185 & 0.8494 & -0.000115 & 0.9072 \\
\hline FCF & - & -0.022553 & $0.0000^{\star * *}$ & -0.021307 & $0.0000^{\star \star \star}$ & -0.020055 & $0.0000^{\star \star \star}$ & -0.021789 & $0.0000^{\star \star \star}$ \\
\hline & $+/-$ & 0.008880 & $0.0001^{\star \star \star}$ & 0.008918 & $0.0001^{* \star \star}$ & 0.007627 & $0.0005^{\star \star \star}$ & 0.008310 & $0.0002^{\star \star \star}$ \\
\hline R-squa & & 0.737747 & & 0.738310 & & 0.732765 & & 0.728646 & \\
\hline Adj R-squared & & 0.710048 & & 0.710672 & & 0.704540 & & 0.699987 & \\
\hline
\end{tabular}

\section{Conclusion}

The study found that the strategy of diversification negatively affects the firm performance. The increasing number of segments proved to give discount effect to the declining performance of the firms. In addition, firms that rely on the sales in a small number of dominant segments decrease the firm's excess value. The market does not appreciate a firm that is supported only by a few dominant segments. However, the result differs in the number of firms that decline and relate to the core business have increased in market performance and accounting performance. The spreading of diversification in many segments without focus on core competencies proved to make business fundamentally fragile, this result is in line with (Prahalad and Hamel, 1990). In addition, the increasing use of debts by the firms with the increasing number of segments results to lower firm performance. On the other hand, the higher investment opportunity affects the increase in excess value and ROA. It is believed that the increase in excess value and ROA in firms with high IOS is due to the existence of earnings management practices, which will be tested in subsequent models.

Further testing proves that diversification strategy and related on core business have effect quadratic on accounting performance and market performance of multi segment firms. In the increasing of number of segments continously, at a certain optimal point will cause discount effect to the firm performance. The findings are consistent with Palich (2000), Thomas (2006), Galván (2007), and Kahloul and Hallara (2010), who state that at a certain point, the increase in firm's diversity will produce discount effects.

Limitations :1) The sample used in this study did not use the entire sector in the grouping sector under the Jakarta Stock Industrial Classification (JASICA). In addition, due to the limitations of the data because this study cannot use a sum of single segment company that is less than 5 companies to be used as basis of imputed value calculation for multisegment company.2)Limitations of the data and exclusion of the service sector, financial sector, as well as the mining sector, causing the majority of samples derived from the number of companies within the manufacturing industry sector. Research should be expanded to include other industries that have different nature and characteristics. Proposed Suggestions for Future Studies: 1)The study of a multi-segment strategy is still very limited in Indonesia, especially in the grouping of related and unrelated diversification. For further research, it is suggested to develop a more diversified studies based on geographical segments inside and outside the country (national and international diversification). 2)This study did not include the service and mining sectors, which actually consists of very few companies that have more than one segment. Further research or studies are suggested to also include companies from the service sector as well as in the mining sector so that all can be summarized in a study or research. 


\section{References}

Adam, Tim dan Vidhan K, Goyal.(2006). The Investment Opportunity Set and Its Proxy Variables: Theory and Evidence. Working paper, January, $1-38$.

Anderson, S.P., dan de Palma, A (1992). Discrete Choice Theory of Product Differentiation. MIT Press, Cambridge.

Bettis, R., dan Hall,W. (1982). Diversification Strategy, Accounting Determined Risk, and Accounting Determined Return. Academy of Management Journal 25(2), $254-264$.

Bauwhede, Heidi V., Willekens, Marleen dan Gaeremynck, Ann. (2003). Audit Firm Size, Public Ownership and Firms' Discretionary Accruals Management. The International Journal of Accounting, (38), 1 - 22.

Berger, Phillip G. dan Eli Ofek. (1995). Diversification's Effect on Firm Value. The Journal of Financial Economics, (37), 39-65.

Bettis, R.A dan Mahajan, V. (1985). Risk-Return Performance of Diversified Firms. Strategi Management Journal, 31, (7).

Bohl, T. Martin dan Pal, Rozalia. Rochester (May 2006). Discount or Premium? New Evidence on Corporate Diversificaion of UK Firms, SSRN Working Paper Series.

Chang, Shao Chi dan Wang, Chi-Feng. (2007). The Effect of Product Diversification Strategies on The Relationship between Internasional Diversification and Firm Performance. Journal of World Business, (42), 61 - 79.

Comment, R dan Jarell, G.A. (1995). Corporate Focus and Stock Returns. Journal of Financial Economics (37), 67 - 87.

Das, T.K. dan Teng, Bing-Sheng. (2000). A Resource - Based Theory of Strategic Alliances. Journal of Management, 26 (1), 31 - 61.

Davis,P.S., Robinson, R.B., Pearce, J.A., Dan Park, S.H. (1992). Business Unit Relatedness and Performance: A look at the Pulp and Paper Industry. Strategic Management Journal, (13), $349-361$.

Del Brio, E., A. Miguel, dan J. Pindado. (2003). Investment and Firm Value: Analysis Using Panel Data, Applied Financial Economics (13), $893-903$.

Ferris, Stephen P., Nilanjan Sen., Chee Yeow Lim dan Gillian H.H. Yeo. (2002). Corporate Focus Versus Diversification: The Role of Growth Opportunities and Cashflow. Journal of International Financial Markets, Institutional and Money (12), 231 - 252.

Galvan, Antonio., Pindado, Julio dan de la Torre, Chabela. (2007). Diversification: Value Ceating or Value Destroying Strategy? Evidence from Using Panel Data, Documento de Trabajo 04/2007.

Gull, F.A. dan Jaggi, B. (1999). An Analysis of Joint Effects od Investment Opportunity Set, Free Cash Flow and Size on Corporate Debt Policy. Review of Quantitative and Accounting (12), 371 - 381.

Gull, F.A., Chen, C.J.P., Tsui, J.S.L. (2003). Discretionary Accounting Accruals, Manager's Incentives, and Audit Fees. Contemporary Accounting Research (20), $441-464$.

Harto, Puji. (2005). Kebijakan Diversifikasi Perusahaan dan Pengaruhnya Terhadap Kinerja: Studi Empiris Pada Perusahaan Publik di Indonesia. SNA VIII, Solo, 297 - 307.

Jacquemine, A.P. dan C.H. Berry. (1979). Entropy Measure of Diversification and Corporate Growth. Journal of Industrial Economics, (27), $359-369$.

Jensen, M dan Meckling, W. (1976). Theory of The Firm : Managerial Behavior, Agency Costs and Capital Structure, Journal of Financial Economics, 3(4), $305-360$.

Kahloul, Ines dan Hallara, Slaheddine. (2010). The Impact of Diversification on Firm Performance and Risk: An Empirical Evidence. International Research Journal of Finance and Economics,(35), 150 - 163.

Kole, S.R. (1991). A Cross-sectional Investigation of Managerial Compensation from an Ex-ante Perspective. Simon Graduate School of Business Administration. University of Rochester

Krishnan, Gopal. V. dan Krishna, R. Kumar. (2005). The Value Relevance of Cash Flows and Accruals: The Role of Investment Opportunity. Working Paper (Feb), $1-47$.

Lang, Larry H.P. and Rene M. Stulz. (1994). Tobin's Q, Corporate Diversification, and Firm Performance. Journal of Political Economy (102), 1248-1280.

Lang, L, E, Ofek, dan R. Stulz. 1996. Leverage, Investment and Firm Growth. Journal of Financial Economics (40), Hal, 3 - 29

Lang, Larry H.P. and Rene M. Stulz. (1994). Asset Sales, Firm Performance, and The Agency Costs of Managerial Discretion. Journal of Financial Economics (37), 3 - 37.

Lamont, Owen dan Christopher, Polk.(2002). Does Diversification Destroy Value? Evidence from The Industry Shocks. Journal of Financial Economics,(63), $51-77$.

Mansi, A.Sattar dan Reeb, David M. (2002). Corporate Diversification: What Gets Discounted? The Journal of Finance, LVII (5).

Markides, C.C.(1992). Consequence of Corporate Refocusing: Ex Ante Evidence, Academy of Management Journal, (35), 398 - 412.

Matraves, Catherine dan Rodrigues, Peter. (2005). Profitability, Diversification, and Multinationality in Leading German and UK Firms. International Journal of Business and Economics, 4 (2), 87 - 105.

Montgomery, C.A. (1994). Corporate Diversification. Journal of Economic Perspective,8(3), 162 - 178.

Morck, Randall., Andrei, Shleifer dan Robert, Vishny. (1990). Do Managerial Objectives Drive Bad Acquisitions? Journal of Finance (45), $31-48$.

Morck, R., Shleifer, A dan Vishney, R.W. (1998). Management Ownership and Market Valuation. Journal of Finance Economics, (20), $293-315$.

Morgado, A. dan J. Pindado. (2003). The Underinvestment and Overinvestment Hypothesis: an Analisis Using Panel Data. European Financial Management, 9 (2), $163-177$.

Nelson, Teresa. (2003). The Persistence of Founder Influence Management, Ownership and Performance Effects at Initial Public 
Offering. Strategic Management Journal, 24 (8),707 - 724.

Palepu, Krishna. (1985). Diversification Strategy, Profit Performance and the Entropy Measure. Strategic Management Journal, (6), 239 $-255$.

Palich L.E., Cardinal LB dan Miller CC. (2000). Curvilinearity in the Diversification Performance Linkage: An Examination Over Three Decades of Research. Strategic Management Journal, 21 (2). Hal. 155 - 174.

Perez G, Rodriquez dan Van Hemmen, Stefan. (2010). Debt, Diversification and Earnings Management. Journal Accounting Public Policy (29), 138 -159.

Prahalad, C.K. dan G. Hamel. (1990). The Core Competence of the Corporation. Harvard Business Review, 71 - 91.

Rajan, R., Servaes, H., Dan Zingales, L. (2000). The Cost of Diversity: The Diversification Discount and Inefficient Investment. Journal of Finance, (55), $35-80$

Rhouland, William dan Zhou, Ping. (2005). Debt, Diversification, and Valuation. Review of -Quantitive Finance and Accounting, (25), 277-291.

Ross, Stephen A., Westerfield and Jaffee. (2008). Corporate Finance, $9^{\text {th }}$ edition, Irwin McGraw-Hill.

Rumelt, R.P.(1982). Diversification Strategy and Profitability, Strategic Management Journal, 3 (4), 359 -369.

Rumelt, R.P. (1984). Towards a Strategic Theory of the Firm. Competitive Strategic Management. Englewood Cliffs, NJ: Prentice Hall, $556-570$.

Servaes, H. (1996). The Value od Diversification During the Conglomerate Merger Wave. Journal of Finance, 51 (4), 1201 - 1225.

Setionoputri et al. (2009). Pengaruh Diversifikasi Korporat terhadap Excess Value Perusahaan Manufaktur, Perdagangan Grosir dan Eceran, serta Properti dan Real Estat yang Terdaftar di BEI Tahun 2005 - 2007, (SNA Palembang 2009).

Shin, Namchul. (2006). The Impact of Information Technology on the Financial Performance of Diversified Firms. Decision Support Systems, (41), $698-707$.

Singh, M., Davidson, W.III dan Suchard,J (2003). Corporate Diversification Strategies and Capital Structure. Quaterly Review of Economics and Finance, (43), $147-167$.

Stern, I dan Henderson, AD. (2004). Within Business Diversification in Technology Intensive Industries. Strategic Management Journal (25), $487-505$.

Thomas, E. Douglas. (2006). International Diversification and Firm Performance in Mexican Firms: A Curvilinear Relationship? Journal of Business Research (59), 501 - 507.

Tifani, Yuliani (2010). Pengaruh Diversifikasi Segmen Usaha Terhadap Nilai Perusahaan Sebelum dan Sesudah Penerapan PSAK No. 5 (Revisi 2000) Tentang Pelaporan Segmen. Skripsi FEUI.

Villalonga, Belen. (2004). Does Diversification Cause the Diversification Discount? Art 1 Financial Management, 33 (2), 5 - 28.

Wernerfelt, B. (1984). A Resourced Based View of the Firm. Strategic Management Journal (5), 171 - 180.

Whited, Toni M. (2001). Is it Inefficient Investment that Causes the Diversification Discount? The journal of Finance, (56), 1667 - 1691.

Xia, Fan. (2007). Three Essays on Corporate Growth, Diversification, Ownership Structure and Corporate Performance, University of California, Los Angeles, 103 pages; AAT 3302558 